\title{
Three silver (I) supramolecular compounds constructed from pyridinium or methylimidazolium polycations: Synthesis, crystal structure and properties
}

\author{
YAO LI, WEN LI ZHANG, HAI JUAN DU, CHAO-HAI WANG, YA BIN LU and YUN-YIN NIU* \\ College of Chemistry and Molecular Engineering, Zhengzhou University, Henan 450001, P R China \\ e-mail: niuyy@zzu.e
}

MS received 9 December 2014; accepted 21 July 2015

\begin{abstract}
Three metal halide cluster supramolecular polymers, $\left\{(\mathrm{TBP})\left[\mathrm{Ag}_{3} \mathrm{Br}_{6}\right]\right\}_{\mathrm{n}}(\mathbf{1}),\left\{(\mathrm{TBI})\left[\mathrm{Ag}_{3} \mathrm{Br}_{6}\right]\right\}_{\mathrm{n}}(\mathbf{2})$ and $\left\{(\mathrm{TBP})\left[\mathrm{Ag}_{3} \mathrm{I}_{6}\right]\right\}_{\mathrm{n}}(3)(\mathrm{TBP}=1,3,5$-tris(N-pyridinium methyl)benzene, TBI=1, 3, 5-tris(methylimidazole methyl)benzene), have been synthesized and characterized by thermoanalysis and spectroscopic methods, as well as single-crystal X-ray diffraction. Complexes 1, 2 and $\mathbf{3}$ all feature a one-dimensional chain structure, which is further extended by electrostatic attraction. The TGA, UV-Vis diffuse reflectance spectra in the solid state and optical band gap properties of the three complexes were also investigated.
\end{abstract}

Keywords. Supramolecule; one-dimension cluster; electrostatic attraction.

\section{Introduction}

In the last two decades, the chemistry of self-assembly in inorganic supramolecular network has attracted extensive attention, owing to the amazing accuracy and high efficiency in control and arrangement of specific building blocks. ${ }^{1-4}$ Supramolecular polymers are constructed generally via binding monomers or components together in macromolecules by highly directional noncovalent interactions such as hydrogen bonding, $\pi-\pi$ interaction, metal-ligand interaction, electrostatic interaction, and so forth..$^{5-7}$ The monomeric components, like guest units, host macromolecules, or even simple host-guest inclusion systems, can be modulated and integrated controllably to construct various supramolecular polymers with specific conformations or functions. ${ }^{8,9}$ Many researchers have been focused on the assembly of inorganic metallates with organic cations as the structure-directing and charge-compensating templates to form extended supramolecular materials. Because of the existence of multiple interaction sites, multication oriented hybrids may present new interesting topologies and novel functions endowed by host-guest interactions. ${ }^{10-14}$ Thus,

*For correspondence an intelligent choice of trivalent cations and transition metal complex anions may yield inorganic-organic hybrid materials with intriguing structure and desirable properties. ${ }^{15-19}$

In the above context, herein we report the synthesis, structure and properties of $\left\{(\mathrm{TBP})\left[\mathrm{Ag}_{3} \mathrm{Br}_{6}\right]\right\}_{\mathrm{n}}$ (1), $\left\{(\mathrm{TBI})\left[\mathrm{Ag}_{3} \mathrm{Br}_{6}\right]\right\}_{\mathrm{n}}(2)$ and $\left\{(\mathrm{TBP})\left[\mathrm{Ag}_{3} \mathrm{I}_{6}\right]\right\}_{\mathrm{n}}$ (3) $(\mathrm{TBP}=1,3,5$-tri(N-pyridinium methyl)benzene, $\mathrm{TBI}=1$, 3, 5-tri(methylimidazole methyl)benzene, scheme 1).

\section{Experimental}

\subsection{Materials and measurements}

Both the two cation templates TBP and TBI were prepared as bromine salt by direct alkylation of pyridinium or 1-methylimidazolium with 1,3,5-tris(bromomethyl)benzene, while acetonitrile served as solvent. $^{20,21}$ Other chemicals and solvents were of reagent grade and used as purchased without further purification. Slow volatile approach at room temperature was used to generate the supramolecules, which was the only way that we got the single crystals (table 1). The IR spectrum was recorded on a Shimadzu IR-435 spectrometer from $\mathrm{KBr}$ pellets (4000$\left.400 \mathrm{~cm}^{-1}\right)$. Elemental analyses $(\mathrm{C}, \mathrm{H}$, and $\mathrm{N}$ ) were carried out on a FLASH EA 1112 elemental analyzer. 
<smiles>c1cc[n+](Cc2cc(C[n+]3ccccc3)cc(C[n+]3ccccc3)c2)cc1</smiles>

(a)

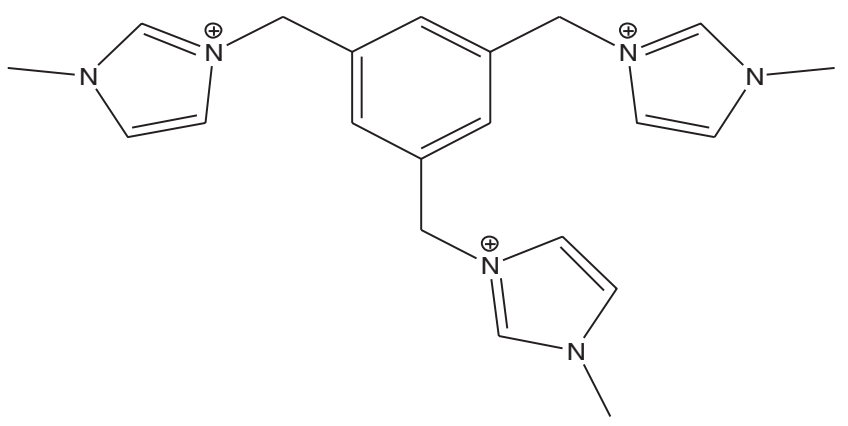

(b)

Scheme 1. The molecular structure of the title trications: (a)TBP; (b)TBI.
A model NETZSCH TG 209 thermal analyzer was used to record simultaneous TG curves in the flowing atmospheric air at $20 \mathrm{~mL} / \mathrm{min}$ at a heating rate of $5^{\circ} \mathrm{C} / \mathrm{min}$ in the temperature range from room temperature to $800^{\circ} \mathrm{C}$ using aluminum crucibles. The UV-Vis diffuse reflectance spectra were measured at UV-Vis-NIR Cary 5000. The purity of the bulk microcrystalline materials obtained from the syntheses was checked by Powder X-ray diffraction analyses. PXRD patterns were recorded using $\mathrm{Cu} K \alpha 1$ radiation on a PAN analytical X'Pert PRO diffractometer.

\subsection{Synthesis of complex 1}

$\left\{(\mathbf{T B P})\left[\mathrm{Ag}_{3} \mathbf{B r}_{6}\right]\right\}_{\mathrm{n}}$ (1) was prepared as follows. A methanol solution of TBP $(0.06 \mathrm{~g}, 0.1 \mathrm{mmol})$ was added to a stirring solution of $\mathrm{AgBr}(0.019 \mathrm{~g}, 0.1 \mathrm{mmol})$ dissolved in $4 \mathrm{~mL}$ DMF- $\mathrm{H}_{2} \mathrm{O}$ in the presence of excess $\mathrm{KBr}(0.08 \mathrm{~g}, 0.4 \mathrm{mmol})$. The precipitate formed in the reaction was dissolved by adding more DMF $(2 \mathrm{~mL})$. The solution was then filtered and slowly

Table 1. Crystal data and structure refinement parameters for $\mathbf{1 , 2}$ and $\mathbf{3}$.

\begin{tabular}{|c|c|c|c|}
\hline Complex & 1 & 2 & 3 \\
\hline Empirical formula & $\mathrm{C}_{24} \mathrm{H}_{24} \mathrm{Ag}_{3} \mathrm{Br}_{6} \mathrm{~N}_{3}$ & $\mathrm{C}_{21} \mathrm{H}_{27} \mathrm{Ag}_{3} \mathrm{Br}_{6} \mathrm{~N}_{6}$ & $\mathrm{C}_{24} \mathrm{H}_{24} \mathrm{Ag}_{3} \mathrm{I}_{6} \mathrm{~N}_{3}$ \\
\hline Formula weight & 1157.53 & 1166.56 & 1439.47 \\
\hline Crystal system & Monoclinic & monoclinic & monoclinic \\
\hline Space group & P-1 & $\mathrm{P} 2{ }_{1} / \mathrm{c}$ & $\mathrm{P} 21 / \mathrm{n}$ \\
\hline a/ $\AA$ & $7.003(4)$ & $6.94956(14)$ & $7.2146(2)$ \\
\hline $\mathrm{b} / \AA$ & $17.255(10)$ & $26.7873(6)$ & $7.2146(2)$ \\
\hline c/ $\AA$ & $26.249(15)$ & $17.3021(4)$ & 26.8494(9) \\
\hline$\alpha /^{\circ}$ & 90 & 90.00 & $17.7538(4)$ \\
\hline$\beta /{ }^{\circ}$ & 90 & $101.204(2)$ & 90.00 \\
\hline$\gamma /{ }^{\circ}$ & $100.272(7)$ & 90.00 & $99.824(2)$ \\
\hline $\mathrm{V} / \AA^{3}$ & $3121(3)$ & $3159.57(12)$ & 90.00 \\
\hline $\mathrm{Z}$ & 4 & 4 & 4 \\
\hline$\rho / \mathrm{Mg} \mathrm{cm}^{-3}$ & 2.464 & 2.452 & 2.822 \\
\hline$\mu / \mathrm{mm}^{-1}$ & 9.565 & 23.844 & 56.837 \\
\hline $\mathrm{F}(000)$ & 2160 & 2184.0 & 2592.0 \\
\hline Crystal size/mm & $0.13 \times 0.12 \times 0.12$ & $0.11 \times 0.10 \times 0.04$ & $0.15 \times 0.10 \times 0.08$ \\
\hline Reflections collected & 17868 & 24303 & 12311 \\
\hline Independent reflections & 10873 & 6167 & 6065 \\
\hline $\mathrm{R}_{\text {int }}$ & 0.0816 & 0.0373 & 0.073 \\
\hline data/restrains/ parameters & $10873 / 360 / 649$ & $6167 / 0 / 329$ & $6065 / 0 / 325$ \\
\hline $\mathrm{T} / \mathrm{K}$ & 293(2) & 291.15 & 291.15 \\
\hline Goodness of fit on $\mathrm{F}^{2}$ & 0.958 & 1.023 & 1.031 \\
\hline $\begin{array}{l}\text { Final } \mathrm{R} \text { indices } \\
{[\mathrm{I}>2 \sigma(\mathrm{I})]}\end{array}$ & $\begin{array}{l}\mathrm{R} 1=0.0686, \\
\mathrm{wR} 2=0.1085\end{array}$ & $\begin{array}{l}\mathrm{R}_{1}=0.0498 \\
\mathrm{wR}_{2}=0.1351\end{array}$ & $\begin{array}{c}\mathrm{R}_{1}=0.0688 \\
\mathrm{wR}_{2}=0.1731\end{array}$ \\
\hline $\mathrm{R}$ indices (all data) & $\begin{array}{l}\mathrm{R} 1=0.2105, \\
\mathrm{wR} 2=0.1507\end{array}$ & $\begin{array}{c}\mathrm{R}_{1}=0.0646 \\
\mathrm{wR}_{2}=0.1472\end{array}$ & $\begin{array}{c}\mathrm{R}_{1}=0.0868 \\
\mathrm{wR}_{2}=0.1917\end{array}$ \\
\hline Largest diff. peak & 0.935 & 1.40 & 1.92 \\
\hline hole $\left(e \AA^{-3}\right)$ & -1.061 & -1.21 & -1.94 \\
\hline
\end{tabular}


evaporated at room temperature. Rod-like crystals of $\left\{(\mathrm{TBP})\left[\mathrm{Ag}_{3} \mathrm{Br}_{6}\right]\right\}_{\mathrm{n}}$ suitable for $\mathrm{X}$-ray analysis were obtained after a week with satisfactory yield of $76 \%$. The product was not soluble in common solvents. FTIR
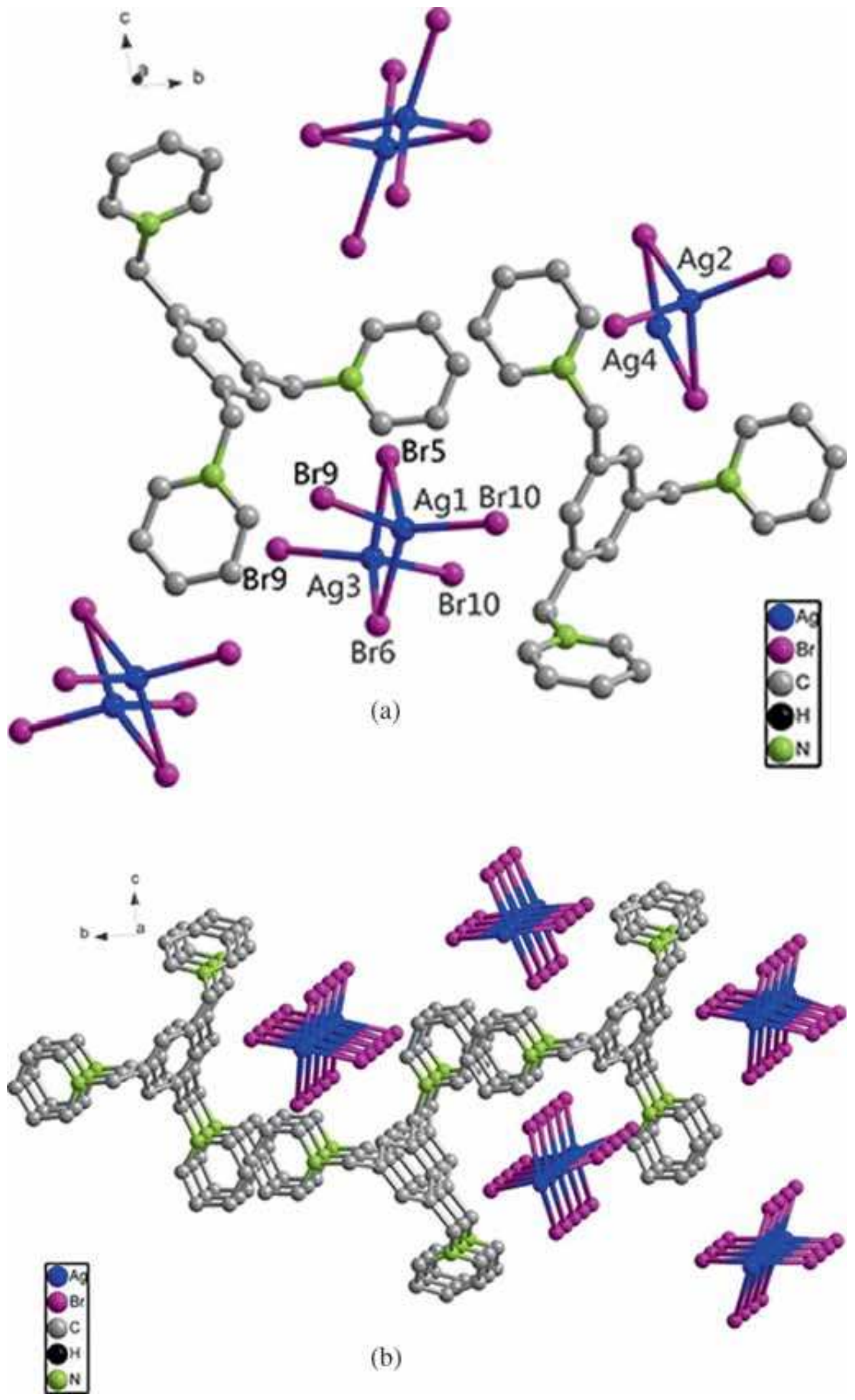

Figure 1. (a) The structural unit of compound 1; (b) the supramolecular architecture of $\mathbf{1}$. 
$\left(\mathrm{KBr}, \mathrm{cm}^{-1}\right)$ : 3438(s), 3048(m), 1698(m), 1577(w), For $\mathrm{C}_{24} \mathrm{H}_{24} \mathrm{Ag}_{3} \mathrm{Br}_{6} \mathrm{~N}_{3}: \mathrm{H}$ 2.11, C 25.08, N 3.66\%.; 1481(m), 1149(s), 690(w), 675(m), 618(s); Anal. Calcd. Found: H 2.06, C 25.23, N 3.43\%.
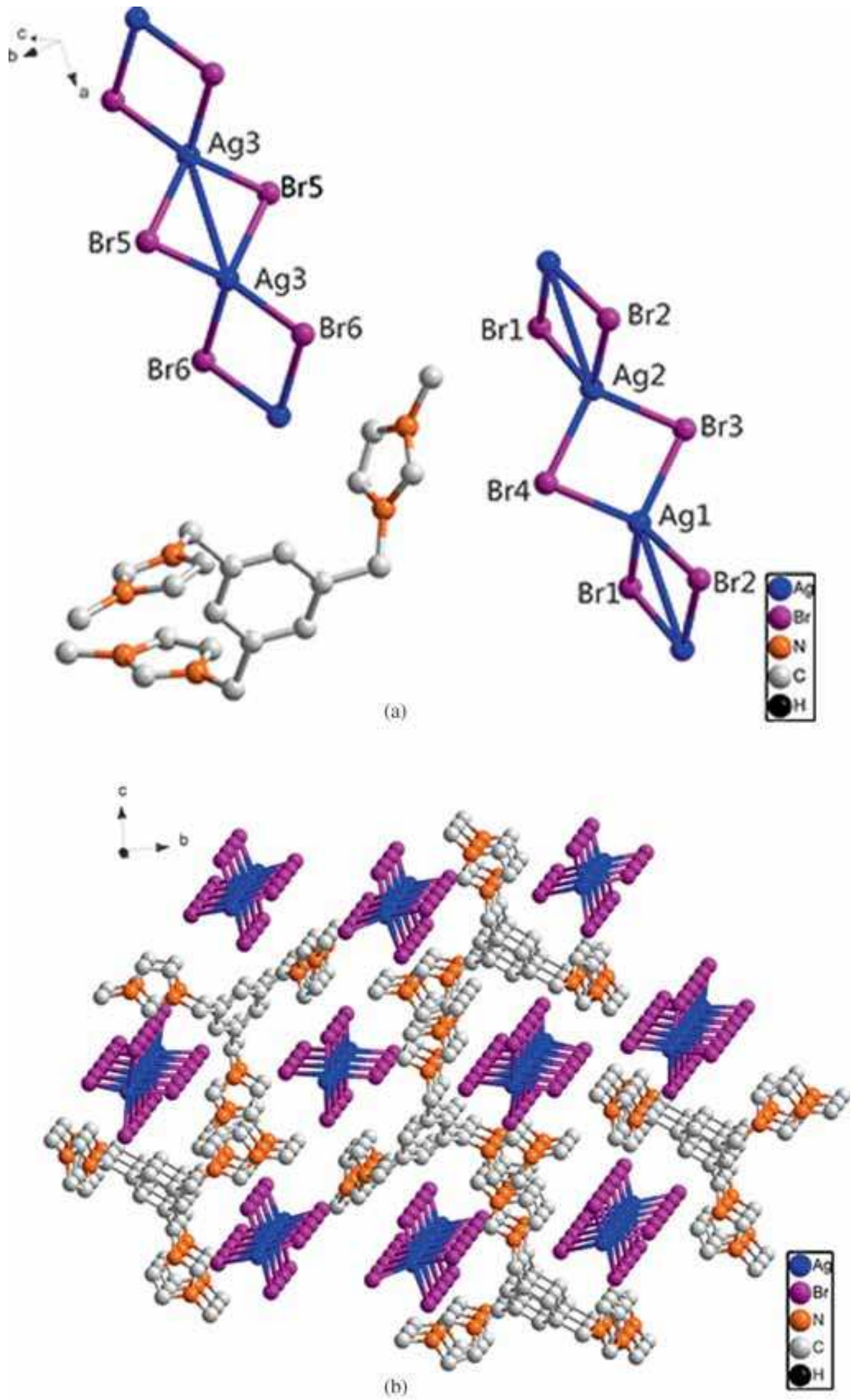

Figure 2. (a) The structural unit of compound 2; (b) the supramolecular architecture of 2. 


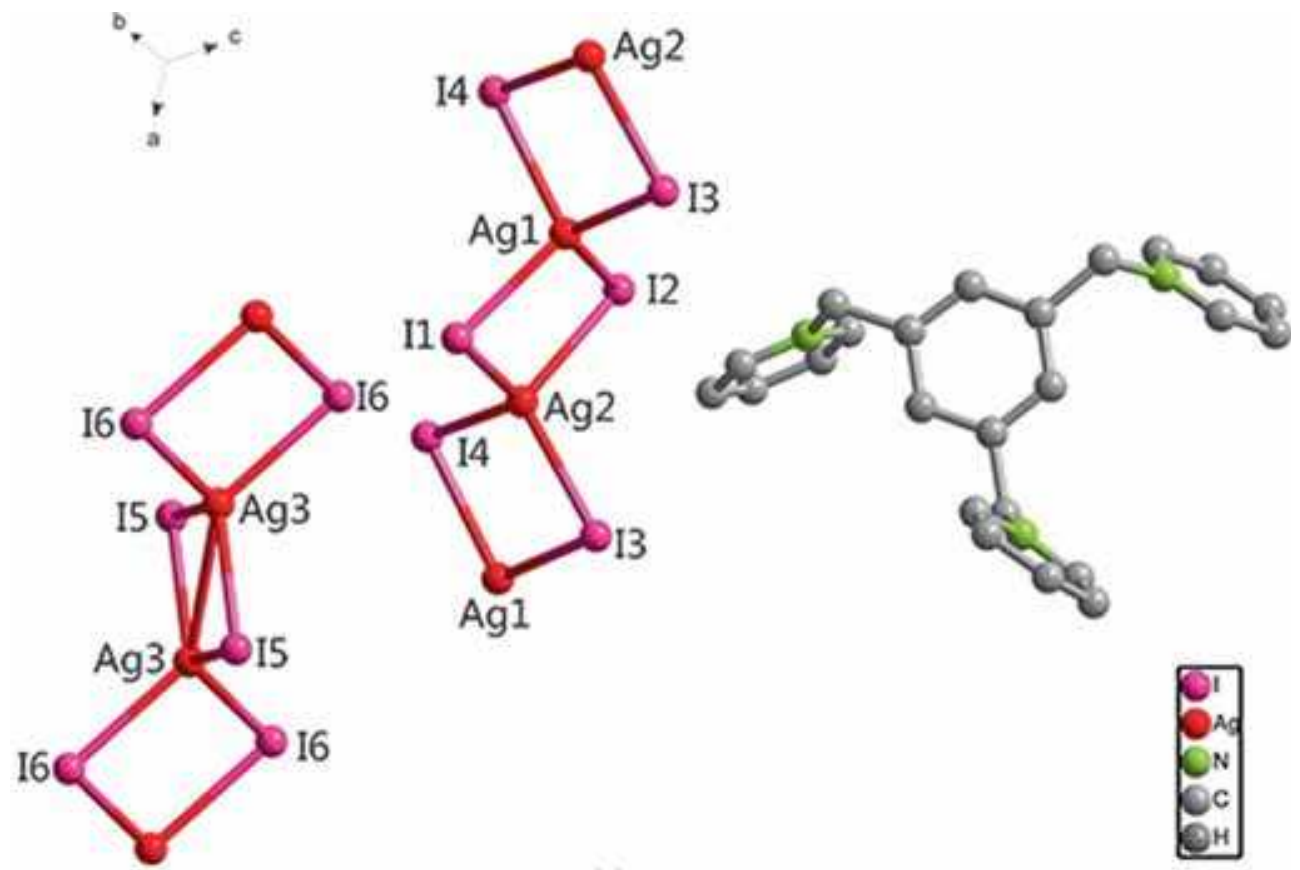

(a)

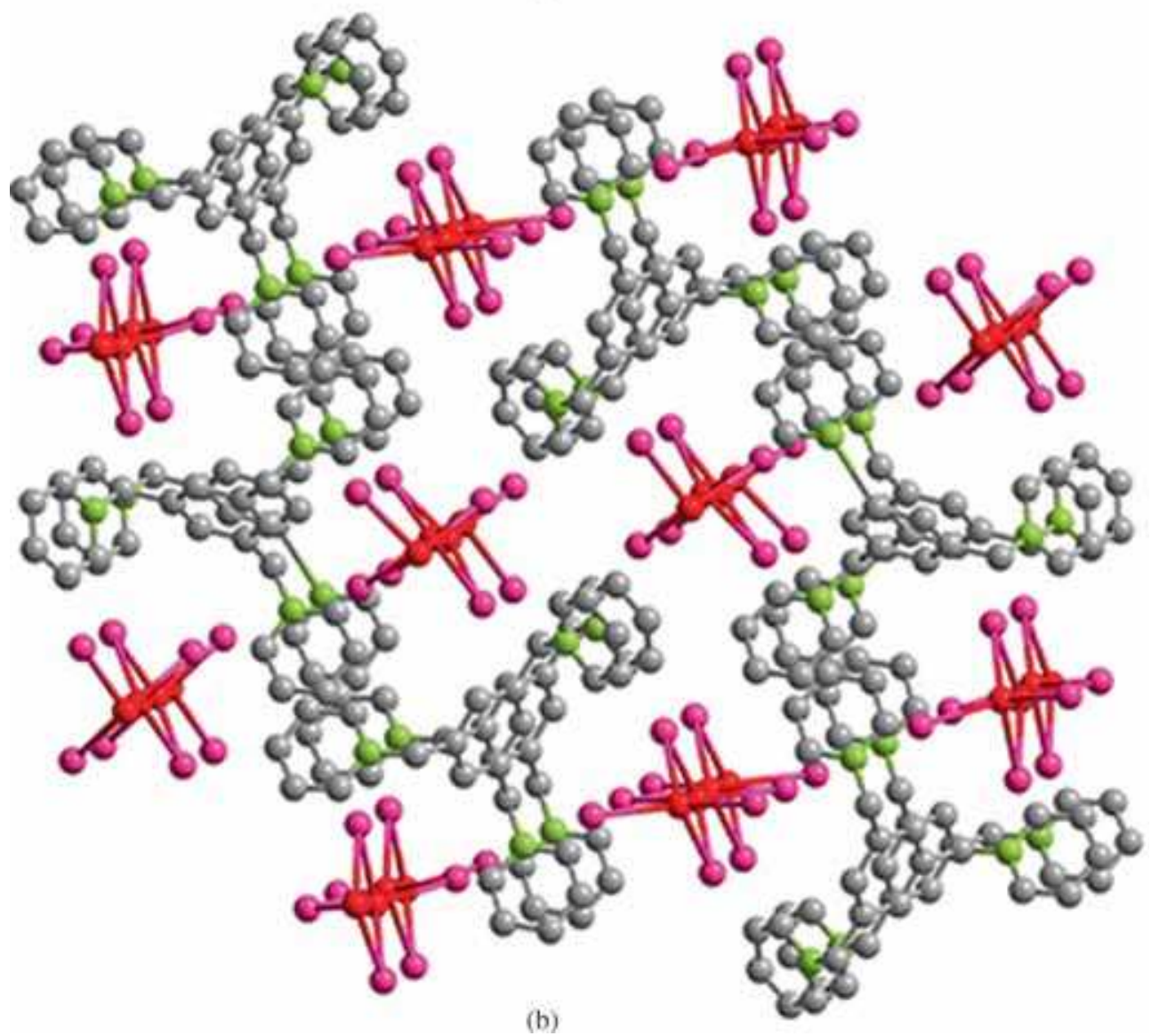

Figure 3. (a) The structural unit of compound 3; (b) the supramolecular architecture of $\mathbf{3}$.

\subsection{Synthesis of complex 2}

$\left\{(\mathbf{T B I})\left[\mathrm{Ag}_{3} \mathbf{B r}_{6}\right]\right\}_{\mathrm{n}}$ (2) was synthesized by a similar procedure to complex $\mathbf{1}$, except use of trication TBI
$(0.06 \mathrm{~g}, 0.1 \mathrm{mmol})$ instead of TBP. Yellow rod-like crystals were obtained with yield of $59 \%$. FTIR (KBr, $\left.\mathrm{cm}^{-1}\right)$ : 3439(m), 3131(s), 3078(s), 1656(w), 1571(s), 
1556(s), 1440(m), 1359(m), 1155(s), 828(s), 618(s). Anal. Calcd. For $\mathrm{C}_{21} \mathrm{H}_{27} \mathrm{Ag}_{3} \mathrm{Br}_{6} \mathrm{~N}_{6}: \mathrm{H}$ 2.33, C 21.62, N 7.20\%; Found: H 2.45, C 21.87, N 6.99\%.

\subsection{Synthesis of complex 3}

$\left\{(\mathbf{T B P})\left[\operatorname{Ag}_{3} \mathbf{I}_{6}\right]\right\}_{\mathbf{n}}(\mathbf{3})$ was synthesized by a similar procedure to complex 1, by using AgI $(0.024 \mathrm{~g}, 0.1 \mathrm{mmol})$ instead of $\mathrm{AgBr}$. Yellow needle-like crystals were obtained with yield of $63 \%$. FTIR $\left(\mathrm{KBr}, \mathrm{cm}^{-1}\right)$ : 3442(s), 1701(w), 1629(s), 1577(m), 1477(s), 1158(s), 1116(m), 674(s); Anal. Calcd. For $\mathrm{C}_{24} \mathrm{H}_{24} \mathrm{Ag}_{3} \mathrm{I}_{6} \mathrm{~N}_{3}: \mathrm{H}$ 1.68, C 20.03, N 2.92\%; Found: H 1.52, C 20.13, N $2.81 \%$.

\section{Results and Discussion}

\subsection{Crystal structures of the complexes}

Compounds 1, 2 and $\mathbf{3}$ all exhibited an unusual onedimensional anion structure, and were composed of two independent $\mathrm{TBP}^{3+}$ and $\mathrm{TBI}^{3+}$ trications as the structural template and one inorganic framework anion, $\left[\mathrm{Ag}_{3} \mathrm{Br}_{6}\right]^{3-}$ or $\left[\mathrm{Ag}_{3} \mathrm{I}_{6}\right]^{3-}$.

Complex 1 crystallizes in monoclinic space group P1. In the polyanionic chain, due to the same coordinated environment, $\operatorname{Ag}(1)$ and $\operatorname{Ag}(3)$ are four-coordinated in a distorted tetrahedral geometry by four $\mu_{2}-\mathrm{Br}$ ions $\left(\mu_{2^{-}}\right.$ $\mathrm{Br} 5, \mu_{2}-\mathrm{Br} 6, \mu_{2}-\mathrm{Br} 9$ and $\left.\mu_{2}-\mathrm{Br} 10\right)$, the same to $\operatorname{Ag}(2)$, which is also four-coordinated in a distorted tetrahedral geometry as shown in figure 1a. The bond lengths of $\mathrm{Ag}(1)$ centers with four $\mu_{2}-\mathrm{Br}$ ions $\left(\mu_{2}-\mathrm{Br}_{5}, \mu_{2}-\mathrm{Br}_{6}, \mu_{2}\right.$ $\mathrm{Br}_{9}$ and $\left.\mu_{2}-\mathrm{Br}_{10}\right)$ are 2.748(3), 2.680(3), 2.750(3) and 2.671(3) A respectively, and the bond angles of $\operatorname{Br}(6)$ $\operatorname{Ag}(1)-\operatorname{Br}(5)$ and $\operatorname{Br}(10)-\operatorname{Ag}(1)-\operatorname{Br}(9)$ are 98.33(8) and $102.30(9)^{\circ}$, respectively. In addition, each of the $\operatorname{Ag}(1)$ and $\operatorname{Ag}(3)$ center is bridged together by four $\mu_{2}-\mathrm{Br}$ ions which are $\mu_{2}-\mathrm{Br} 5, \mu_{2}-\mathrm{Br} 6, \mu_{2}-\mathrm{Br} 9$ and $\mu_{2}-\mathrm{Br} 10$ to form $\mathrm{AgBr}_{2} \mathrm{Ag}$ unit respectively, as shown in figure $1 \mathrm{~b}$.

Complex 2 crystallizes in monoclinic space group $\mathrm{P} 2{ }_{1} / \mathrm{c}$. In the crystal of compound 2, the central $\mathrm{Ag}(1)$ ion was four coordinated, completed via four $\mu_{2}-\mathrm{Br}$ ions in a typical distorted tetrahedral geometry similar to complex 1 . The coordination environment of $\operatorname{Ag}(1)$ is as shown in figure $2 \mathrm{a}$. The $\mathrm{Ag}-\mathrm{Br}$ distances ranged from 2.664 to $2.761 \AA$ and the bond angles of $\operatorname{Br}(2)$ $\operatorname{Ag}(1)-\operatorname{Br}(1)$ and $\operatorname{Br}(3)-\operatorname{Ag}(1)-\operatorname{Br}(4)$ are 103.39(3) and 97.64(3) $)^{\circ}$ respectively. Two adjacent $\mathrm{Ag}$ ions were bridged by two $\mu_{2}-\mathrm{Br}$ ions $\left(\mu_{2}-\mathrm{Br} 1\right.$ and $\left.\mu_{2}-\mathrm{Br} 2\right)$ to form an $\mathrm{AgBr}_{2} \mathrm{Ag}$ rhombohedral unit. Interestingly, compared with compound $\mathbf{1}$, there existed a weak $\mathrm{Ag} \cdots \mathrm{Ag}$ contact with an $\mathrm{Ag} \cdots \mathrm{Ag}$ distance of $3.372 \AA$ in the $\mathrm{AgBr}_{2} \mathrm{Ag}$ units bridged by $\mu_{2}-\mathrm{Br}(1)$ and $\mu_{2}-\operatorname{Br}(2)$ ions, and the $\mathrm{Ag} \cdots \mathrm{Ag}$ bonds also appear in the $\mathrm{AgBr}_{2} \mathrm{Ag}$ units bridged by two $\mu_{2}$-Br5 ions with an Ag $\cdots$ Ag distance of $3.270 \AA$. As shown in figure $2 b$, the two types of $\mathrm{AgBr}_{2} \mathrm{Ag}$ units were alternately linked by sharing $\mathrm{Ag}$ centers to form an infinite chain.

The complex 3 consists of $[\mathrm{TBP}]^{3+}$ cations and $\left[\mathrm{Ag}_{3} \mathrm{I}_{6}\right]^{3-}$ anions and it also exhibits one-dimensional structure. The structure unit and the crystal packing diagram of complex 3 are shown in figure $3 \mathrm{a}$. The bond lengths of $\operatorname{Ag}(1)$ centers with four $\mu_{2}$-I ions $\left(\mu_{2^{-}}\right.$ I1, $\mu_{2}-\mathrm{I} 2, \mu_{2}-\mathrm{I} 3$ and $\left.\mu_{2}-\mathrm{I} 4\right)$ are $2.849,2.884,2.836$ and $2.924 \AA$, respectively, and the bond angles of $\mathrm{I}(1)-\mathrm{Ag}(1)-\mathrm{I}(2), \mathrm{I}(3)-\mathrm{Ag}(1)-\mathrm{I}(4)$ are 103.54 and $98.15^{\circ}$ respectively. The distances of $\mathrm{Ag}(2)-\mathrm{I}$ range from 2.812 to $2.895 \AA$, and the bond angles of $\mathrm{I}(1)-\mathrm{Ag}(2)-\mathrm{I}(2), \mathrm{I}(3)$ $\operatorname{Ag}(2)-\mathrm{I}(4)$ are 104.50 and $99.40^{\circ}$ respectively. Being like with compound $\mathbf{2}$, there also existed a weak

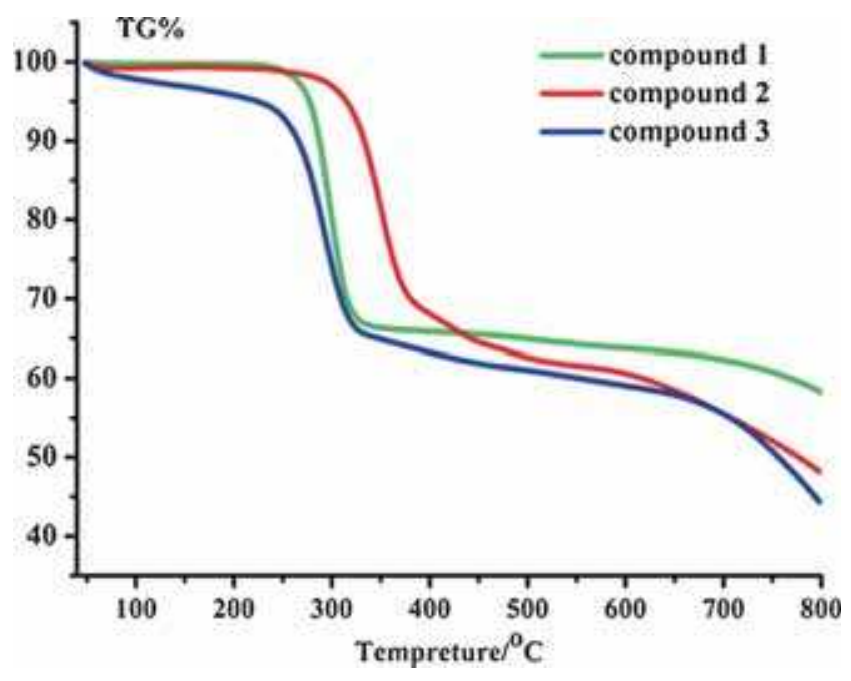

Figure 4. The TG curves of compounds 1-3 in a flowing air of $20 \mathrm{~mL} / \mathrm{min}$ at a heating rate of $5^{\circ} \mathrm{C} / \mathrm{min}$.

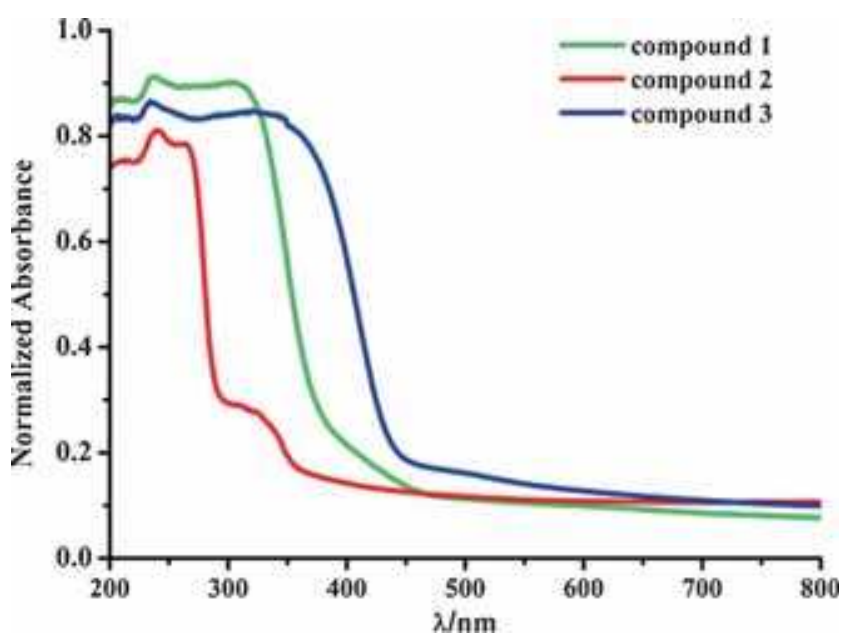

Figure 5. The UV-Vis spectra of compound 1-3. 

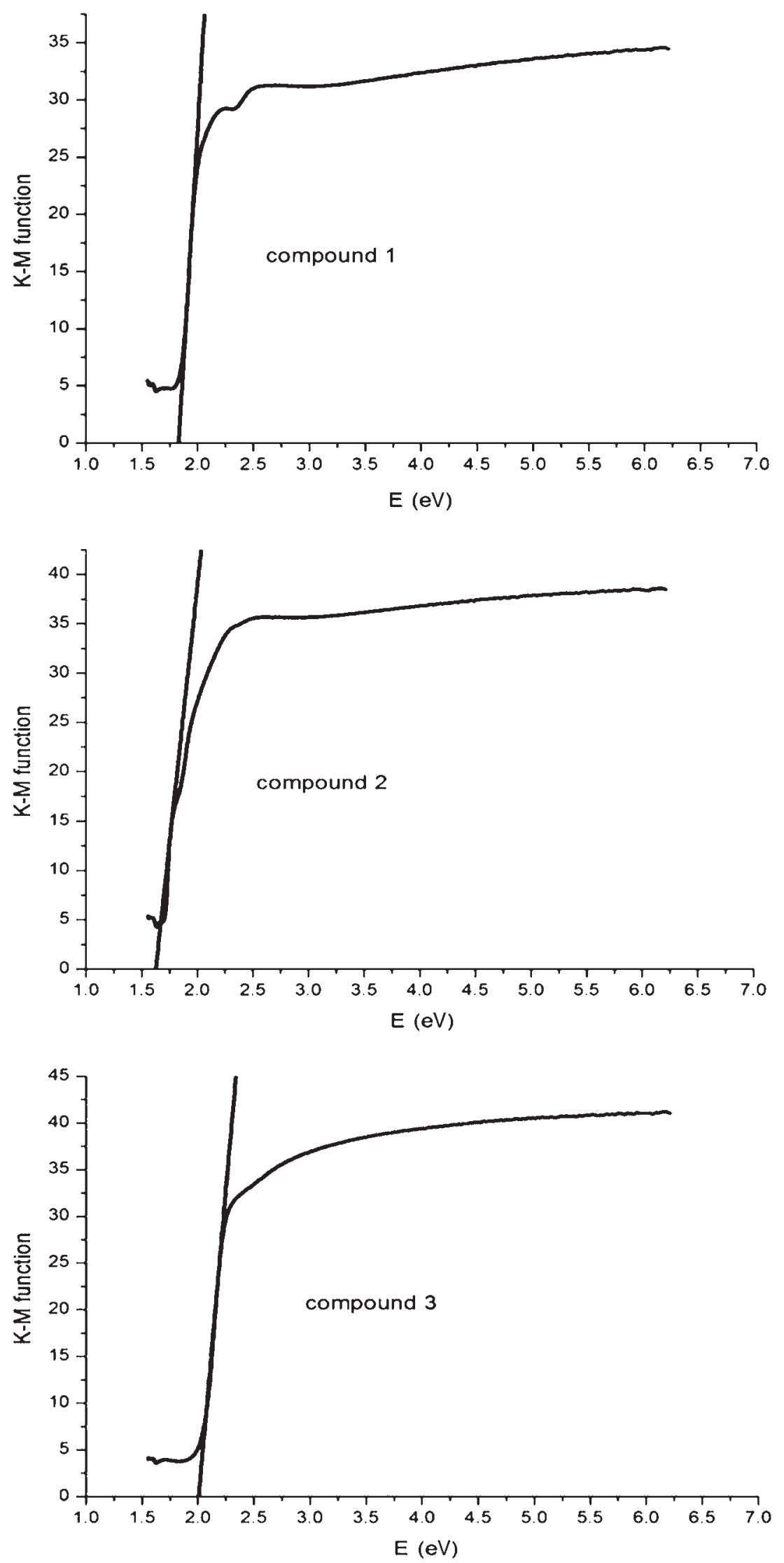

Figure 6. K-M function versus energy (eV) curve compounds $\mathbf{1}, \mathbf{2}$ and $\mathbf{3}$. 
Ag . A Ag contact with an Ag ‥ Ag distance of $3.308 \AA$ in the $\mathrm{AgI}_{2} \mathrm{Ag}$ units bridged by two $\mu_{2}$-I5 ions, while the $\mathrm{Ag} \cdots \mathrm{Ag}$ bond did not appear in the $\mathrm{AgI}_{2} \mathrm{Ag}$ units bridged by $\mu_{2}-\mathrm{I} 1$ and $\mu_{2}-\mathrm{I} 2$ ions. As shown in figure $3 \mathrm{~b}$, the two types of $\mathrm{AgI}_{2} \mathrm{Ag}$ units were alternately linked by sharing Ag centers to form an infinite chain.

\subsection{Thermogravimetric analysis}

The thermogravimetric analysis experiments of complexes 1, 2 and $\mathbf{3}$ were investigated under air atmosphere, using a temperature gradient from room temperature to $800^{\circ} \mathrm{C}$ at a rate of $5^{\circ} \mathrm{C} / \mathrm{min}$ as shown in figure 4. Complex $\mathbf{1}$ is similar to complex $\mathbf{2}$, which remains stable up to $260^{\circ} \mathrm{C}$. Then weight loss occurs in the range of $260-320^{\circ} \mathrm{C}$ (complex 2 is $260-450^{\circ} \mathrm{C}$ ), which corresponds to the release of cation TBP (TBI in complex 2). We think that the further weight loss is due to the collapse of the anionic skeleton and decomposition to $\mathrm{Ag}_{2} \mathrm{O}$. In complex 3, the moisture of the sample caused the slight loss in weight under $250^{\circ} \mathrm{C}$. Then weight loss occurs in the range of $250-300^{\circ} \mathrm{C}$, which corresponds to the release of cation TBP. The weight loss from 573 to $727^{\circ} \mathrm{C}$, the same as in compounds 1 and 2, which can be attributed to anionic skeleton collapsing and $\mathrm{Ag}_{2} \mathrm{O}$ decomposing.

\section{$3.3 \quad U V$-Vis property}

The UV-Vis absorption spectra of $\mathbf{1 - 3}$ in the solid state are shown in figure 5. The electronic spectra of $\mathbf{1}$ and 3 show similar absorbance with the bands centered around $230 \mathrm{~nm}$ suggesting the domination of $\pi \rightarrow \pi^{*}$ transition from benzene ring in templates. The absorption band of compound 2 observed at $\sim 240 \mathrm{~nm}$ shows a strong resemblance to those of $\mathbf{1}$ and $\mathbf{3}$ on account of $\pi \rightarrow \pi^{*}$ transition with the benzene ring due to conjugation effect.

\subsection{Study of optical band gap}

To explore conductivity of the compounds $\mathbf{1 ,} \mathbf{2}$ and $\mathbf{3}$, the UV-Vis diffuse reflectance spectra were measured to obtain their band gaps $\left(E_{\mathrm{g}}\right)$. The band gap $\left(E_{\mathrm{g}}\right)$ was determined as the intersection point between the energy axis and the line extrapolated from the linear portion of the absorption edge in a plot of Kubelka-Munk function $F$ against energy $E .{ }^{22,23}$ Kubelka-Munk function, $F=(1-R)^{2} / 2 R$, was converted from the recorded diffuse reflectance data, where $R$ is the reflectance of an infinitely thick layer at a given wavelength. The
$F$ versus $E$ plots, are shown in figure 6 , and the $E_{\mathrm{g}}$ values assessed from the respective steep absorption edge are $1.83 \mathrm{eV}$ for $\mathbf{1}, 1.63 \mathrm{eV}$ for 2 and $2.02 \mathrm{eV}$ for $\mathbf{3}$, which indicate that these complexes are potential semi-conductive materials. ${ }^{23}$

\subsection{XRPD analysis}

The experimental powder X-ray diffraction patterns in comparison with simulated XRD patterns from single-crystal X-ray data of the three coordination polymers are shown in figure $\mathrm{S} 1$. Their peak positions are in good consistency with each other, indicating the phase purity of the samples.

\section{Conclusion}

In summary, three metal halide cluster supramolecular polymers were obtained via slow evaporation approach at room temperature from methanol and DMF system through trication-templated self-assembly strategy. The inorganic moiety in compounds $\mathbf{1}, \mathbf{2}$ and $\mathbf{3}$ take single chain framework with TBP and TBI trications surrounding them. These novel supramolecular networks provide new insights into the construction of solidstate materials, in particular modular open framework or porous materials, which is a subject of current intense investigation. Exploiting the methodology described here in more complex systems is under way. ${ }^{24}$

\section{Supplementary Information}

The supporting information, available at www.ias.ac.in/ chemsci, contains important bond distances and angles for 1-3, experimental and simulated powder XRD patterns. CCDC1034460, 1034461 and 1034462 contain the supplementary crystallographic data for compounds 1-3, respectively. These data can be obtained free of charge from The Cambridge Crystallographic Data Centre via http://www.ccdc.cam.ac.uk/conts/retrieving. html.

\section{Acknowledgements}

Research efforts in the Niu group are supported by the National Science Foundation of China (Nos. 21171148, J1210060).

\section{References}

1. Li L, Yue J M., Qiao Y Z, Niu N N and Hou H W 2013 Cryst. Eng. Comm. 133835 
2. Wang Z M, Hu K L, Gao S and Kobayashi H 2010 Adv. Mater. 221526

3. Zhu L L, Ma X, Ji F Y, Wang Q C and Tian H 2007 Chem.-Eur. J. 139216

4. Sun S, Zhang R, Anderson S, Pan J, Akermark B and Sun L 2006 Chem. Commun. 404195

5. Brunsveld L, Folmer J B, Meijer E W and Sijbesma R P 2001 Chem. Rev. 1014071

6. De Greef T F A, Smulders M M J, Wolffs M, Schenning A P H J, Sijbesma R P and Meijer E W 2009 Chem. Rev. 1095687

7. Aida T, Meijer E W and Stupp S I 2012 Science 335813

8. Ma X and Tian H 2014 Acc. Chem. Res. 471971

9. Sakamoto K, Takashima Y, Yamaguchi H and Harada A 2007 J. Org. Chem. 72459

10. Gomez-Casado A, Dam H H, Yilmaz M D, Florea D, Jonkheijm P and Huskens J 2011 J. Am. Chem. Soc. 133 10849

11. Badjica J D, Nelson A, Cantrill S J, Turnbull W B and Stoddart J F 2005 Acc. Chem. Res. 38723

12. Lee M, Niu Z, Slebodnick C and Gibson H W $2010 \mathrm{~J}$. Phys. Chem. B 1147312

13. Jiang X M, Zhang M J, Zeng H Y, Guo G C and Huang J S 1999 J. Am. Chem. Soc. 121452
14. Hu J S, Q L Zhang M D, Yao X Q, Li Y Z, Guo Z J, Zheng H G and Xue Z L 2012 Chem. Commun. 48681

15. Lee J W, Samal S, Selvapalam N, Kim H J and Kim K 2003 Acc. Chem. Res. 36621

16. Liu D, Li H X, Liu L L, Wang H M, Li N Y, Ren Z G and Lang J P 2010 Cryst. Eng. Comm. 123708

17. Yan X Z, Xu D H, Chi X D, Chen J Z, Dong S Y, Ding X, Yu Y H and Huang F H 2012 Adv. Mater. 24362

18. Yue J M, Niu Y Y, Zhang B, Ng S W and Hou H W 2011 Cryst. Eng. Comm. 132571

19. Niu Y Y, Wu B L, Guo X L, Song Y L, Liu X C, Zhang H Y, Hou H W, Niu C Y and Ng S W 2008 Cryst. Growth Des. 82393

20. Baron M, Tubaro C, Basato M, Natile M M and Graiff C 2013 J. Organomet. Chem. 723108

21. Ibrahim H, Koorbanally N A, Ramjugernath D, Bala M D, Nyamori V O and Anorg Z 2012 Allg. Chem. 638 2304

22. Xia Y, Wu P F, Wei Y G, Wang Y and Guo H Y 2006 Cryst. Growth Des. 6253

23. Liu H Y, Bo L, Yang J, Liu Y Y, Ma J F and Wu H 2011 Dalton Trans. 409782

24. Li L, Yue Z C, Zhang W L, Zhang B, Niu Y Y and Hou H W 2013 Cryst. Eng. Comm. 158395 